\title{
$\mathrm{HL}-60$ 세포에서 disulfiram의 항암작용과 미토콘드리아 안정성에 대한 연구
}

\author{
신효원 · 한 용·주홍구* \\ 제주대학교 수의과대학 수의과학연구소
}

\section{Anti-tumor activity and mitochondrial stability of disulfiram in HL-60 cells}

\author{
Hyowon Shin, Yong Han, Hong-Gu Joo*
}

Veterinary Medical Research Institute, College of Veterinary Medicine, Jeju National University, Jeju 63243, Korea

\begin{abstract}
Disulfiram (DSF) is a member of the dithiocarbamate family that can bind copper. Recent studies have shown that DSF has anti-cancer activities, but the mechanism has not been clarified. Therefore, it is important to study the action mechanism of DSF to maximize its anticancer effects. A human leukemia cell line, HL-60, was used in this study. HL-60 cells were treated with DSF and the cellular metabolic activity was measured. DSF increased the cell death of HL-60 cells in annexin V-fluorescein isothiocyanate/ propidium iodide staining analysis. In addition, DSF decreased the mitochondrial membrane potential (MMP) of the HL-60 cells. The cytotoxicity of DSF on HL-60 cells was observed at $0.4 \mu \mathrm{M}$. Interestingly, the reduction of MMP by DSF was recovered by N-acetylL-cysteine, an inhibitor of reactive oxygen species (ROS) production. This suggests that the decrease in MMP by DSF is closely related to the production of ROS in HL-60 cells, which indicates the relationship between the apoptosis of HL-60 cells by DSF and the role of the mitochondria. This study provides clinicians and researchers with valuable information regarding the anti-cancer activity of DSF in terms of the action mechanism.
\end{abstract}

Keywords: disulfiram, HL-60 cells, mitochondrial membrane potential, cell death, reactive oxygen species

\section{*Corresponding author}

Hong-Gu Joo

Veterinary Medical Research Institute, College of Veterinary Medicine, Jeju National University, 102 Jejudaehak-ro, Jeju 63243, Korea

Tel: +82-64-754-3379

Fax: +82-64-756-3354

E-mail: jooh@jejunu.ac.kr

ORCID

Hyowon Shin

https://orcid.org/0000-0002-2635-7580

Yong Han

https://orcid.org/0000-0002-5728-4716

Hong-Gu Joo

https://orcid.org/0000-0002-1505-8761

Conflict of Interest

The authors declare no conflicts of interest.

Received: August 08, 2019

Revised: October 15, 2019

Accepted: October 29, 2019

\section{서론}

Copper $(\mathrm{Cu})$ 는 종양세포의 증식에 필수적인 미량 원소이며, 다양한 암에서 높은 수준의 $\mathrm{Cu}$ 가 검출되기 때문에 $\mathrm{Cu}$ 는 잠재적인 종양 특이적 지표로 사 용될 수 있는 것으로 알려져왔다[1,2]. Disulfiram (DSF)은 70여년 전부터 알코올중독 치료제로 사용되던 약물이며, $\mathrm{Cu}$ 와 결합할 수 있는 dithiocarbamate family 물질 중 하나이다[3]. 최근의 연구에 따르면 DSF는 여러 종류의 고형암에 세포독성을 보였으며 기존의 항암제의 기능을 향상시켰으 나, 그 작용기전에 대해서는 거의 규명되지 않았다[4-6].

DSF는 높은 수준의 endoplasmic reticulum (ER) stress를 갖는 세포에서 활성산소를 생성하고 unfolded protein response (UPR)를 악화시키고 세포자 멸사를 유도한다. 이를 통해 구강 편평상피암 세포와 이종 이식에서의 증식 을 감소시킬 수 있다[7].

ER stress 반응은 ER막에 위치하는 3가지 신호전달 단백질인 inositolrequiring protein-1 $\alpha$ (IRE1 $\alpha$ ), protein kinase RNA (PKR)-like ER kinase (PERK), 그리고 activating transcription factor (ATF)6에 의해 매개된다[8]. IRE1 $\alpha$ 는 p38 mitogen-activated protein kinases (MAPK)를 활성화시켜[9] transcriptional factor $\mathrm{C} / \mathrm{EBP}$ homologous protein $(\mathrm{CHOP})$ 를 인산화시키고 [10], ATF6는 serine protease site-1 (S1P)과 metalloprotease site-2 protease $(\mathrm{S} 2 \mathrm{P})$ 에 의해 절단되어 그 파편이 $\mathrm{CHOP}$ 를 인산화시키며[8], PERK은 ATF4 를 활성화시켜 $\mathrm{CHOP}$ 를 인산화시킨다[10]. 인산화된 $\mathrm{CHOP}$ 은 세포사멸에 기 여하는 유전자들, 예를 들어, endoplasmic reticulum oxidoreductase-1(Erola), $\mathrm{DR} 5$ 를 활성화시켜 세포사(cell death)를 유도한다.

HL-60세포는 사람의 백혈병 세포로서, 뚜렷한 골수성세포 특징을 갖고 있 
으며 생체 외에서 여러 가지 세포유형으로 분화하도록 유도 될 수 있다. DSF-Cu복합체는 doxorubicin이 처리된 HL-60 에서 $\mathrm{JNK} / \mathrm{c}-J u n$ pathway의 활성화에 대한 민감성을 높여서 세포사를 유도한다[11].

앞선 연구에서 DSF가 ER stress에 의해 유도되는 UPR과 $\mathrm{DSF}-\mathrm{Cu}$ 복합체에 의한 JNK/c-Jun pathway 활성화에 의한 세포사멸에 의해 항암효과를 일으킨다는 사실이 확인되었다 [7,11]. 하지만 다양한 세포사에서 중요한 역할을 하는 미토 콘드리아에 대한 DSF의 관련성에 대한 연구는 매우 미흡한 실정이다. 본 연구에서는 HL-60세포에 DSF를 농도 별로 처 리한 후 HL-60 세포의 증식반응과 미토콘드리아 막전위 (mitochondrial membrane potential, $\mathrm{MMP}$ )를 측정하여 $\mathrm{DSF}$ 의 세포독성과 미토콘드리아의 기능에 미치는 영향에 대하 여 연구하였다.

\section{재료 및 방법}

\section{세포와 시약}

DSF (Sigma, USA; catalog number PHR1690)는 dimethyl sulfoxide (DMSO)에 녹여 $100 \mathrm{mM}$ 용액을 stock solution 으로 사용하였다. 본 연구에서는 HL-60 세포(Korean Cell Line Bank, Republic of Korea)를 사용하였으며, DSF를 농 도별로 처리한 후 $37^{\circ} \mathrm{C}, 5 \% \mathrm{CO}_{2}$ 의 조건에서 배양한 후 분 석에 이용하였다. 4-Phenylbutyric acid (4-PBA)는 DMSO 에 녹여 $10 \mu \mathrm{M}$ 용액으로, N-acetyl-L-cysteine (NAC)는 deionized water에 녹여 $3 \mathrm{M}$ 농도로 stock solution을 만들 어 사용하였다. 모든 약물은 냉동보관 하였으며, 필요에 따 라 적정 농도로 추가 희석하여 사용하였다.

\section{$\mathrm{HL}-60$ 세포의 대사활성도 측정}

HL-60세포를 $1 \times 10^{5}$ cells $/ \mathrm{mL}$ 의 농도로 96-well culture plate에 넣은 후 DSF를 농도별로 처리한 후 배양하였다. 배 양이 끝난 후 HL-60 세포에 3-(4,5-dimethylthiazol-2-yl)2,5-diphenyltetrazoliumbromide (MTT, Sigma) 용액을 0.5 $\mathrm{mg} / \mathrm{mL}$ 농도로 넣고 4시간 동안 처리하였다[12]. 살아있는 세포에 의해 생긴 crystal violet을 녹이기 위해 $10 \%$ sodium dodecyl sulfate용액을 well당 $100 \mu \mathrm{L}$ 씩 넣어 2시간동안 반 응시켰다. Microplate reader (Molecular Devices, USA)를 이용하여 흡광도 $(570 \mathrm{~nm})$ 를 분석하였다.

\section{세포 morphology 관찰과 핵 염색}

HL-60세포의 모양을 관찰하고 사진촬영을 위해, 디지털카 메라가 장착된 도립현미경(IX70; Olympus, Japan)을 사용하 였다. 또한 세포의 핵을 염색하기 위해 Hoechst 33342 용 액을 $1.25 \mu \mathrm{g} / \mathrm{mL}$ 농도로 처리하여 $37^{\circ} \mathrm{C}$ 에서 10 분간 염색하 였다[13]. 염색된 세포는 형광현미경 $\left(\mathrm{ZOE}^{\mathrm{TM}}\right.$ Fluorescent Cell Imager; Bio-Rad, USA)을 이용해 관찰하고 사진촬영을 했다.

\section{유세포분석}

HL-60세포를 24-well culture plate에 $1 \times 10^{5}$ cells $/ \mathrm{mL}$ 의 농도로 넣어 배양하고 DSF를 농도별로 처리하였다. 4-5일간 배양한 후 미토콘드리아 막전위를 측정하기 위해 Rhodamine 123 용액을 $0.25 \mu \mathrm{g} / \mathrm{mL}$ 의 농도로 암실조건에서 30 분간 염색 하였다. HL-60세포의 세포사 측정을 위해 annexin Vfluorescein isothiocyanate (FITC)와 propidium iodide (PI) 용액으로 염색하였다[14]. 유세포분석은 CytoFLEX와 CytExpert software (Beckman Coulter, USA)를 이용해 분 석하였다.

\section{통계분석}

Fig. 1은 평균 \pm 표준편차로 나타냈다. 일원분산분석(oneway analysis of variance) 후에 Turkey 검정으로 유의성을 확인하였다. 통계처리 후 $p$ value가 0.05 미만인 경우 유의 한 것으로 판단하였다.

\section{결 과}

\section{$\mathrm{HL}-60$ 세포의 대사활성도에 대한 DSF의 효과}

흡광도를 $570 \mathrm{~nm}$ 에서 측정한 결과, $0.016 \mu \mathrm{M}$ 농도부터 0.4 $\mu \mathrm{M}$ 농도까지 비교하였을 때 DSF $0.016 \mu \mathrm{M}$ 은 대조군과 유 의한 차이가 없었지만 $0.4 \mu \mathrm{M}$ 처리군에서 세포의 대사활성 도가 급격히 감소하였다(Fig. 1).

\section{DSF에 의한 HL-60세포의 세포사 증가}

Annexin V-FITC/PI 염색을 실시한 결과, DSF의 농도에 비례하여 annexin V 또는 PI 양성세포의 수가 증가하였으며, DSF $0.4 \mu \mathrm{M}$ 처리 HL-60의 세포사가 현저하게 증가하였다. $\mathrm{DSF}$ 에 의해 early apoptosis (annexin $\mathrm{V}+\mathrm{PI}-$ ), late apoptosis (annexin $\mathrm{V}+/ \mathrm{PI}+$ ), necrosis (annexin $\mathrm{V}-/ \mathrm{PI}+$ ) 된 세포의

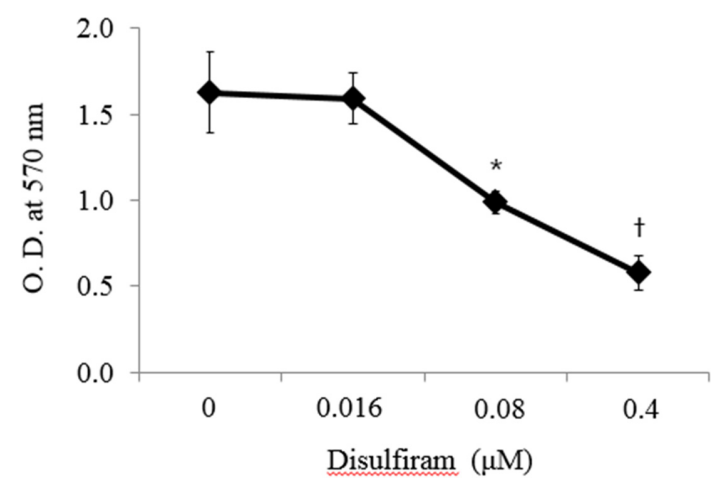

Fig. 1. Effect of DSF on the metabolic activity of HL-60 cells. The cells were cultured in 96-well culture plates. The concentration range of DSF was $0-0.4 \mu \mathrm{M}$; the cells were treated by a stepwise 5-fold dilution. A MTT assay was performed 5 days after drug treatment. The data are presented as the means \pm standard deviation. DSF, disulfiram; MTT, 3(4,5-dimethylthiazol-2-yl)-2,5-diphenyltetrazoliumbromide; O.D., optical density. ${ }^{*} p<0.01,{ }^{\dagger} p<0.001$. 
비율이 증가하였는데, 특히 DSF $0.4 \mu \mathrm{M}$ 농도에서 early apoptosis (annexin $\mathrm{V}+/ \mathrm{PI}-$ )의 비율이 현저히 증가하였다 (Fig. 2).
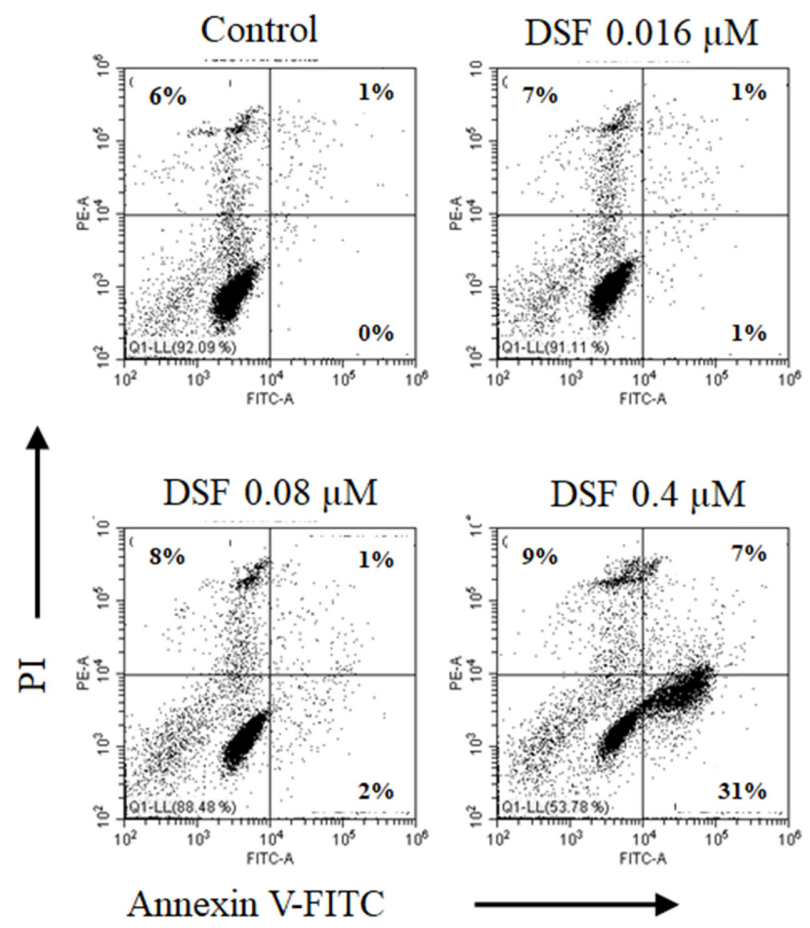

Fig. 2. Effect of DSF on the apoptosis and necrosis of HL-60. The cells were cultured in 24-well culture plates and treated with DSF over the concentration range, $0-0.4 \mu \mathrm{M}$, by 5 -fold dilution. After a 4-day treatment, annexin V-FITC/PI staining was performed. The quadrants of the dot plot indicate live cells (annexin $\mathrm{V}-/ \mathrm{PI}-$ ), the cells in early apoptosis (annexin $\mathrm{V}+/ \mathrm{PI}-$ ), late apoptosis (annexin $\mathrm{V}+/ \mathrm{PI}+$ ), and necrosis (annexin $\mathrm{V}-/ \mathrm{PI}+)$. The number of quadrants indicates the cell percentage. DSF, disulfiram; FITC, fluorescein isothiocyanate; PI, propidium iodide.

\section{A}

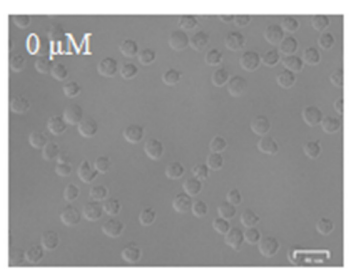

B

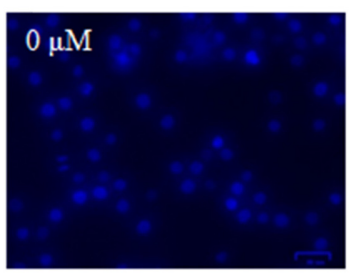

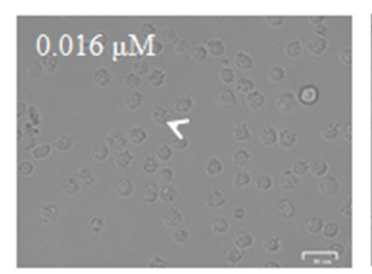

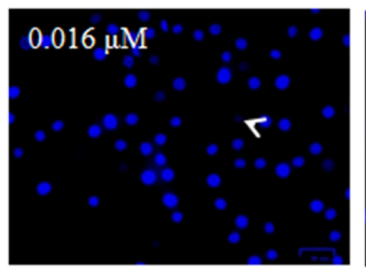

DSF에 의한 HL-60세포의 미토콘드리아 막전위 변화 DSF가 HL-60 세포의 미토콘드리아에 미치는 영향을 알아 보기 위하여 HL-60 세포에 DSF를 농도별로 처리하고 $\mathrm{MMP}$ 를 비교하였다. 대조군 $(0 \mu \mathrm{M})$ 에 비해 DSF $0.4 \mu \mathrm{M}$ 농 도로 처리된 MMP가 현저히 감소하였다(Fig. 3).
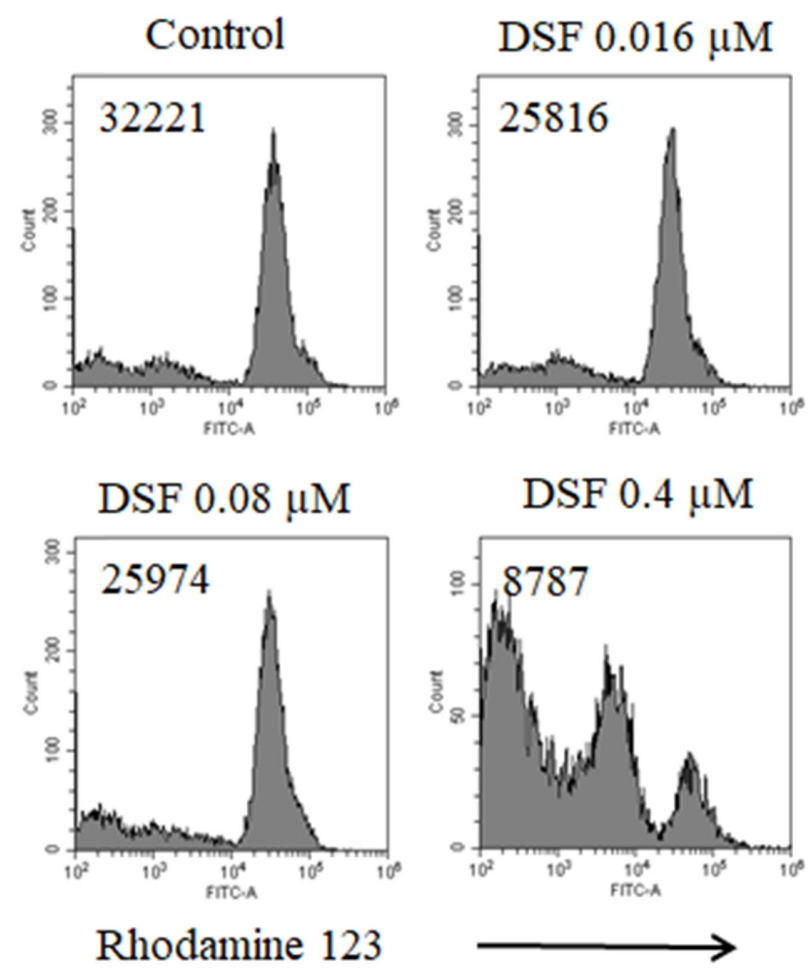

Fig. 3. Reductive effect of DSF on the MMP of HL-60. The cells were setup and treated, as in Fig. 2, and harvested after 4 days. The control cells and DSF-treated cells were stained with a Rhodamine 123 solution and analyzed by flow cytometry. The number in histograms indicates the mean fluorescence intensity. DSF, disulfiram; MMP, mitochondrial membrane potential.
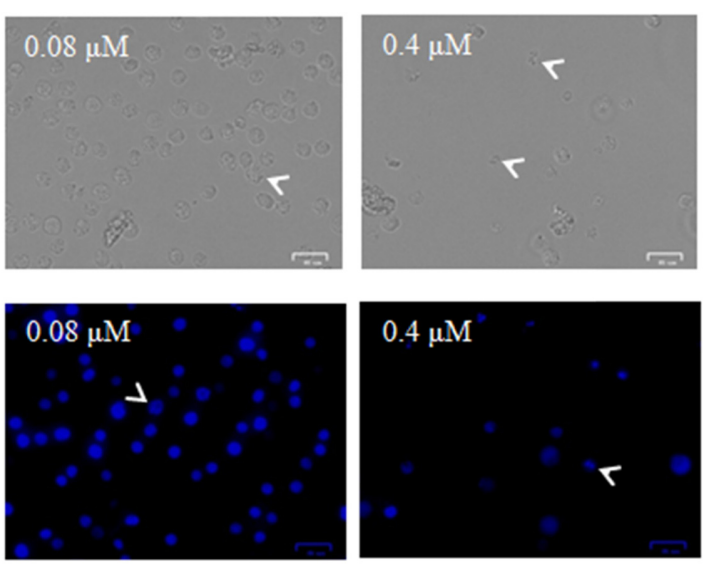

Fig. 4. Morphological alteration of HL-60 cells after the DSF treatment. The cells were setup and treated with DSF (0-0.4 $\mu$ M), as shown in Fig. 2. After 3 days, Hoechst 33342 staining was performed. Compared to the control group, visible apoptosis characters (arrow), e.g. chromatin condensation, membrane blebbing, and nuclear breakdown, were observed in the HL-60 cells treated with DSF $(\mathrm{bar}=100 \mu \mathrm{m})$. DSF, disulfiram. 

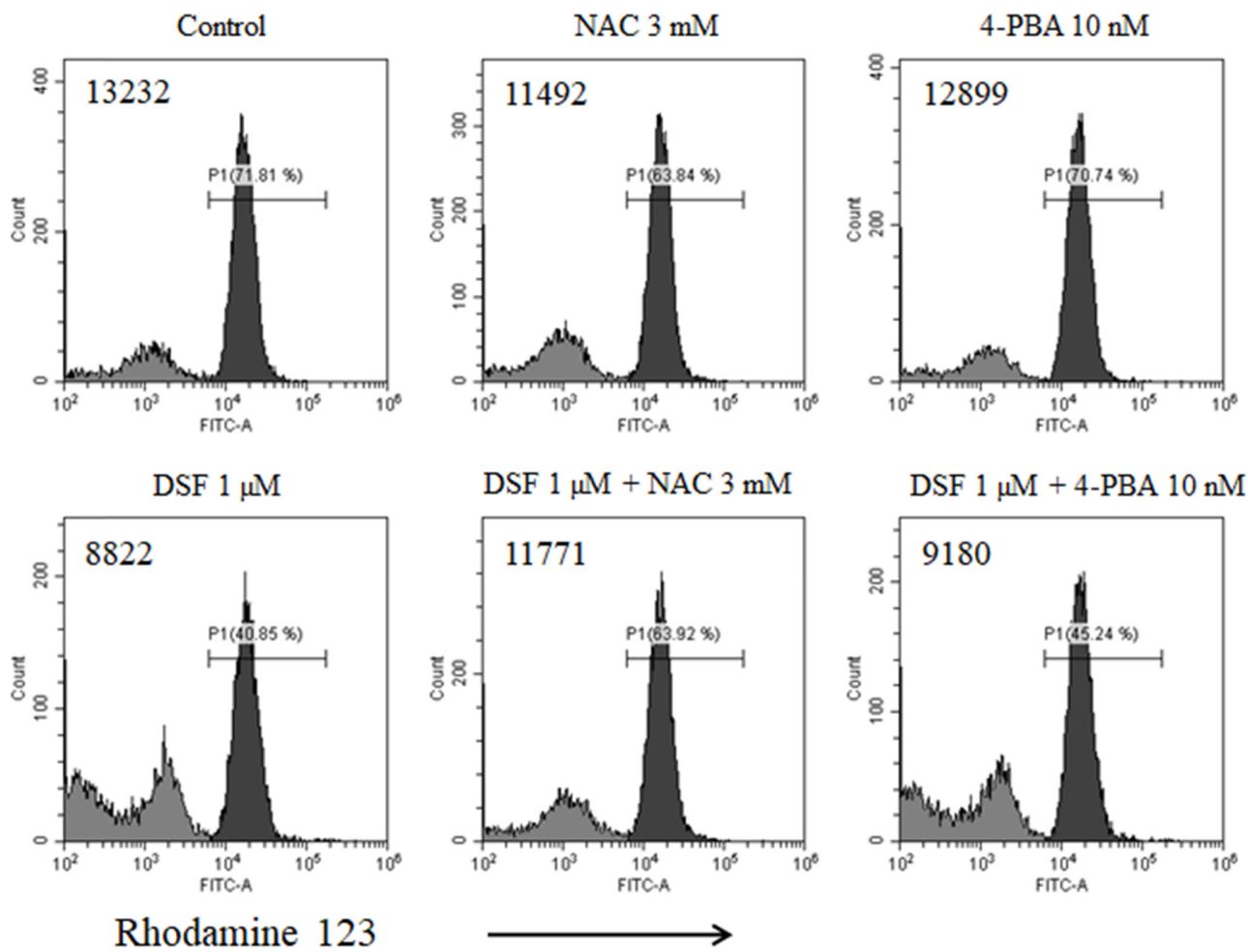

\section{DSF $1 \mu \mathrm{M}+4-\mathrm{PBA} 10 \mathrm{nM}$}

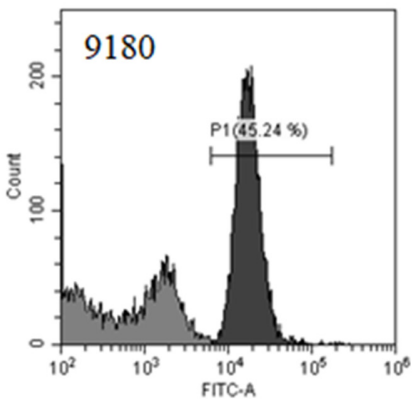

Rhodamine 123

Fig. 5. DSF and NAC combined effect on the decrease in MMP in HL-60 cells. The cells were cultured in 24-well culture plates. Each well was treated with the control (medium alone), $3 \mathrm{mM} \mathrm{NAC,} 10 \mathrm{nM} 4$-PBA in the absence or presence of $1 \mu \mathrm{M}$ DSF. The treated cells were harvested after 4 days. The cells were stained with a Rhodamine 123 solution and analyzed by flow cytometry. The number in the histograms indicates the mean fluorescence intensity. P1 denotes the percentage of high MMP cells. DSF, disulfiram; NAC, N-acetyl-L-cysteine; MMP, mitochondrial membrane potential; 4-PBA, 4-Phenylbutyric acid.

\section{DSF에 의한 HL-60세포의 형태 변화}

$\mathrm{DSF}$ 를 처리한 후 세포형태를 비교한 결과 대조군에 비해 $\mathrm{DSF}$ 를 처리한 농도에 비례하여 깨져 있는 세포의 수가 증가 하였다(Fig. 4A). 또한 형광현미경을 이용해 DSF에 의한 $\mathrm{HL}-60$ 세포의 핵 형태변화를 관찰한 결과, DSF의 농도에 비례하여 염색질의 응축, 핵의 파괴, 세포막의 붕괴와 같은 세포사의 특징들이 나타났다(Fig. 4B).

\section{$\mathrm{NAC}$ 과 4-PBA가 DSF의 효과에 미치는 영향}

Reactive oxygen species (ROS) 억제제인 NAC와 ER stress 억제제인 4-PBA를 처리한 후 $\mathrm{MMP}$ 를 측정하였다. $\mathrm{DSF} 1 \mu \mathrm{M}$ 처리군은 대조군에 비해 MMP가 급격히 감소하 였다 (71.81\%에서 $40.85 \%$ 로 감소). DSF와 함께 NAC, 4$\mathrm{PBA}$ 를 처리한 결과 $\mathrm{NAC}$ 는 $\mathrm{DSF}$ 에 의한 $\mathrm{MMP}$ 저하를 막았 지만(63.92\%), 4-PBA는 MMP저하 방지효과가 작았다 (45.24\%). NAC와 4-PBA가 MMP의 변동에 미치는 단독효 과는 약하거나 거의 없는 것으로 나타났다(Fig. 5).

\section{고 찰}

$\mathrm{DSF}$ 는 $\mathrm{Cu}$ 와 결합할 수 있는 dithiocarbamate family 물 질 중 하나이며, 최근 항암효과를 갖는 것으로 밝혀졌다[15].
본 연구에서는 DSF의 항암효과 즉 세포사멸 효과와 미토콘 드리아의 관련성을 알아보았다. 사람의 백혈병세포주인 HL60 세포에 DSF를 처리하였을 때 세포활성도와 미토콘드리아 의 막전위가 감소하여 DSF가 HL-60세포의 활성을 억제하는 것을 알 수 있었다. 또한 annexin V-FITC/PI 염색에서 대조 군과 비교하였을 때 DSF처리군은 생존한 세포 수가 감소하 고 apoptosis한 세포의 수가 증가하여 세포사를 유도하는 사 실을 확인했다.

본 연구에서 $\mathrm{MMP}$ 를 측정한 결과, 대조군에 비하여 $\mathrm{DSF}$ $0.08-0.4 \mu \mathrm{M}$ 농도에서 감소하였다. MMP 실험뿐만 아니라 HL-60 세포에 Hoechst 33342 염색한 후 핵의 형태를 관찰 할 때에도 비슷한 결과를 보였다. DSF를 만들 때 사용되는 용매인 DMSO의 영향을 배제하기 위해 DSF 농도별 처리 시 에 $\mathrm{DMSO}$ 의 함량을 동일하게 처리하여 실험을 실시하였다.

Disulfiram은 ER stress에 의한 UPR의 악화, ROS의 관 련성 등 다양한 항암기전이 제시되어왔다 [7,16]. 본 연구에서 는 HL-60에 대한 disulfiram의 항암효과가 미토콘드리아와 관련이 있음을 확인했다. 또한 세포의 미토콘드리아와 기존 에 제기된 항암기전인 ER stress, ROS의 상관관계를 확인하 고자 하였다. 4-PBA는 ER stress 경로를 억제하는데 사용되 는 물질이며[17], NAC는 ROS의 생산을 억제하는 데 사용 된다[18]. DSF의 세포사 작용기전을 알아보기 위하여 DSF 
$1 \mu \mathrm{M}$ 농도에 각각 $\mathrm{NAC}$ 와 4-PBA를 처리한 결과, $\mathrm{HL}-60$ 세포에서 $\mathrm{DSF}$ 에 의한 $\mathrm{MMP}$ 의 감소가 $\mathrm{NAC}$ 에 의해 현저히 억제되어 MMP가 회복되는 것을 확인할 수 있었다. 이를 통 해 $\mathrm{DSF}$ 에 의한 MMP감소는 ROS가 중간 매개체로 사용되 는 것으로 추정된다.

미토콘드리아의 전자전달계는 세포 내에서 ROS를 생성하 는 주된 소기관이며, ROS생산을 통해 세포자멸사(apoptosis) 신호전달에 밀접하게 연결되어 있다[19]. Vinblastine을 포함 한 다수의 항암제는 ROS의존성 활성화를 통해 항암효과를 나타낸다[20]. 따라서 DSF에 의한 세포사와 미토콘드리아 간 에 밀접한 관련이 있음을 추측해볼 수 있다.

본 연구의 결과를 종합하면, $\mathrm{DSF}$ 의 항암기전은 미토콘드 리아와 관련성이 있다. 이런 점은 $\mathrm{DSF}$ 와 미토콘드리아의 기 능을 교란하는 항암제와 함께 병용하였을 때 상승효과를 나 타낼 수 있다는 가능성을 보여주고 있다. 또한 각각의 약물 을 기존보다 저농도로 투여함으로써 환자에게 미치는 부작 용을 감소시킬 수 있을 것으로 기대된다. 향후 미토콘드리아 와 $\mathrm{DSF}$ 의 관련성에 대한 전후 인과관계에 대해 알아보는 실험과, DSF와 다른 항암제의 상승효과에 대해 학인하는 실 험이 필요하다.

\section{References}

1. Gupte A, Mumper RJ. Elevated copper and oxidative stress in cancer cells as a target for cancer treatment. Cancer Treat Rev 2009;35:32-46.

2. Zuo XL, Chen JM, Zhou X, Li XZ, Mei GY. Levels of selenium, zinc, copper, and antioxidant enzyme activity in patients with leukemia. Biol Trace Elem Res 2006;114:41-53.

3. Eneanya DI, Bianchine JR, Duran DO, Andresen BD. The actions of metabolic fate of disulfiram. Annu Rev Pharmacol Toxicol 1981;21:575-596.

4. Cen D, Gonzalez RI, Buckmeier JA, Kahlon RS, Tohidian NB, Meyskens FL Jr. Disulfiram induces apoptosis in human melanoma cells: a redox-related process. Mol Cancer Ther 2002;1:197-204.

5. Wang W, McLeod HL, Cassidy J. Disulfiram-mediated inhibition of NF- $\mathrm{BB}$ activity enhances cytotoxicity of 5fluorouracil in human colorectal cancer cell lines. Int J Cancer 2003;104:504-511.

6. Wickström M, Danielsson K, Rickardson L, Gullbo J, Nygren $\mathrm{P}$, Isaksson A, Larsson $\mathrm{R}$, Lövborg $\mathrm{H}$. Pharmacological profiling of disulfiram using human tumor cell lines and human tumor cells from patients. Biochem Pharmacol 2007;73:25-33.

7. Shah O'Brien P, Xi Y, Miller JR, Brownell AL, Zeng Q, Yoo GH, Garshott DM, O’Brien MB, Galinato AE, Cai P, Narula N, Callaghan MU, Kaufman RJ, Fribley AM. Disulfiram (Antabuse) activates ROS-dependent ER Stress and apoptosis in oral cavity squamous cell carcinoma. J Clin Med 2019; 8:E611.

8. Sano R, Reed JC. ER stress-induced cell death mechanisms. Biochim Biophys Acta 2013;1833:3460-3470.

9. Ron D, Hubbard SR. How IRE1 reacts to ER stress. Cell 2008;132:24-26.

10. Yamaguchi $\mathrm{H}$, Wang HG. CHOP is involved in endoplasmic reticulum stress-induced apoptosis by enhancing DR5 expression in human carcinoma cells. J Biol Chem 2004;279:45495-45502.

11. Xu B, Shi P, Fombon IS, Zhang Y, Huang F, Wang W, Zhou S. Disulfiram/copper complex activated $\mathrm{JNK} / \mathrm{c}$-jun pathway and sensitized cytotoxicity of doxorubicin in doxorubicin resistant leukemia HL60 cells. Blood Cells Mol Dis 2011;47:264-269.

12. Kim SY, Joo HG. Evaluation of adjuvant effects of fucoidan for improving vaccine efficacy. J Vet Sci 2015;16:145-150.

13. Jang JY, Moon SY, Joo HG. Differential effects of fucoidans with low and high molecular weight on the viability and function of spleen cells. Food Chem Toxicol 2014;68:234-238.

14. Moon SY, Joo HG. Anti-inflammatory effects of 4,4'diaminodiphenyl sulfone (dapsone) in lipopolysaccharide-treated spleen cells: selective inhibition of inflammation-related cytokines. Korean J Vet Res 2015;55:199-204.

15. Navrátilová J, Jungová P, Vanhara P, Preisler J, Kanicky V, Smarda J. Copper ions regulate cytotoxicity of disulfiram to myeloid leukemia cells. Int J Mol Med 2009;24:661-670.

16. Park YM, Go YY, Shin SH, Cho JG, Woo JS, Song JJ. Anticancer effects of disulfiram in head and neck squamous cell carcinoma via autophagic cell death. PLoS One 2018;13: e0203069.

17. Wiley JC, Meabon JS, Frankowski H, Smith EA, Schecterson LC, Bothwell M, Ladiges WC. Phenylbutyric acid rescues endoplasmic reticulum stress-induced suppression of APP proteolysis and prevents apoptosis in neuronal cells. PLoS One 2010;5:e9135.

18. Halasi M, Wang M, Chavan TS, Gaponenko V, Hay N, Gartel AL. ROS inhibitor N-acetyl-L-cysteine antagonizes the activity of proteasome inhibitors. Biochem J 2013;454:201-208.

19. Mignotte B, Vayssiere JL. Mitochondria and apoptosis. Eur J Biochem 1998;252:1-15.

20. Fang J, Nakamura H, Iyer AK. Tumor-targeted induction of oxystress for cancer therapy. J Drug Target 2007;15:475-486. 